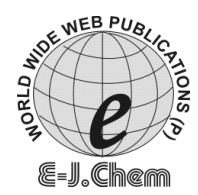

http://www.e-journals.net
ISSN: 0973-4945; CODEN ECJHAO

E-Journal of Chemistry

2009, 6(S1), S117-S122

\title{
Potentiometric and UV Spectral Studies of Binary and Ternary Complexes of Some Metal Ions with $N$-Acetylcysteine and Amino Acids
}

\author{
SHAESTA QUYOOM* and BADR-UD-DIN KHAN \\ Department of Chemistry, \\ University of Kashmir, Srinagar, India. \\ ms.shaesta@rediffmail.com
}

Received 12 March 2009; Accepted 15 May 2009

\begin{abstract}
The formation constants of the binary 1:1 and 1:2 complexes of $\mathrm{Cu}(\mathrm{II})$, $\mathrm{Zn}(\mathrm{II}), \mathrm{Cd}(\mathrm{II}), \mathrm{Hg}(\mathrm{II})$, and $\mathrm{Pb}$ (II) with $N$-acetylcysteine (NAC) and 1:1:1 ternary complexes of the said metal ions with NAC as a primary ligand and some biologically important amino acids as secondary ligands have been determined potentiometrically in aqueous medium. Acid dissociation constants of the ligands used and the formation constants of the binary and the ternary complexes were determined at $25{ }^{0} \mathrm{C}$ and in ionic strength $\mathrm{I}=0.1 \mathrm{~mol} \mathrm{dm}^{-3}\left(\mathrm{KNO}_{3}\right)$. The formation constants of the 1:1 complexes were found to be higher than 1:2 complexes and the metal ions follow the order $\mathrm{Hg}(\mathrm{II})>\mathrm{Cu}(\mathrm{II})>\mathrm{Cd}(\mathrm{II})>\mathrm{Zn}(\mathrm{II})$. In addition UV-spectral studies of the NAC-Metal (II) complexes have also been conducted at appropriate $\mathrm{pH}$ values to give further information about the structural nature of NAC- Metal (II) complexes in aqueous medium.
\end{abstract}

Keywords: Formation constants, $N$-Acetylcysteine (NAC), Ternary complexes.

\section{Introduction}

For understanding the nature and the extent of coordination of soft toxic metal ions e.g. $\mathrm{Pb}(\mathrm{II}), \mathrm{Hg}(\mathrm{II}), \mathrm{Cd}$ (II) etc. with soft bioligands in physiological systems a thorough study of these ions with thiol groups of cysteine and its derivatives can not only serve as models for cysteine containing proteins and enzymes ${ }^{1}$ but also such low molecular weight thiols which form soluble complexes can possibly act as detoxifying agents. One such cysteine derivative is model peptide $\mathrm{N}$-acetylcysteine (NAC) which on one side has a free $\mathrm{SH}$ group and on the other side its $\alpha$-amino group is been protected with acetyl group. In fact acetyl group forms the simplest peptide bond in proteins ${ }^{2}$. In view of the above observations, NAC seems to be an ideal candidate for chelating toxic metal ions; therefore a knowledge of the formation constants is essential for exploring its possible use as an antidote for various metal toxicities. 
Stability constants of various metal ions with sulfur containing amino acids have been studied by many workers ${ }^{3-8}$. However very few studies have been reported on the stability constants of NAC-metal(II) complexes ${ }^{9,10}$ we therefore consider it worthwhile to study the interaction of NAC with various metal ions. In this study we report the acid dissociation constants of $\mathrm{NAC}$, and the formation constants of the binary 1:1 and 1:2 complexes of $\mathrm{Cu}(\mathrm{II}), \mathrm{Zn}(\mathrm{II}), \mathrm{Cd}(\mathrm{II}), \mathrm{Hg}$ (II) and $\mathrm{Pb}$ (II) with $\mathrm{N}$-acetylcysteine (NAC) .

Due the ubiquitous presence of various free amino acids in the biological systems it also becomes necessary to study their interactions as well, and one of the common ways in which they interact is the formation of ternary complexes .Ternary complexes ${ }^{11}$ are known to play a very important role in various biological processes including detoxification of toxic cations. Taking these facts into consideration we are also reporting the stability constants of ternary complexes of said metal ions involving NAC as a primary ligand and some selected amino acids as secondary ligands. Such studies with NAC are of very importance as sulfur is one of the most important donor atoms in vivo ${ }^{12}$.

Besides the potentiometric studies, the coordinating nature and the stoichiometry of the resulting NAC-metal(II) (binary complexes) was also studied by carrying out UV-spectral studies at $\mathrm{pH} 10$.

\section{Experimental}

The titration cell consisted of a glass beaker equipped with a magnetic stirrer, a microburet delivery tube and combined glass electrode system. All the potentiometric measurements were carried out on a Lab India digital $\mathrm{pH}$-meter. The $\mathrm{pH}$-meter was calibrated in both the acidic and alkaline region by using standard buffer tablets.

\section{Material and solutions}

$\mathrm{N}$-Acetylcysteine, histidine, tyrosine, phenylalanine were Merck p.a. All ligands used were of reagent grade of the highest purity and were recrystallized whenever necessary. Stock solutions were prepared by dissolving precisely weighed amounts of the ligands in doubledistilled water. The metal salts (as nitrates) were provided by $\mathrm{BDH}$. Nitric acid, $\mathrm{KOH}, \mathrm{KNO}_{3}$ and Borax were from Merck p.a.

\section{Procedure}

\section{Potentiometric studies}

The following solutions were prepared in a total volume of $50 \mathrm{~mL}$ and titrated potentiomectrically against $0.234 \mathrm{~mol} \mathrm{dm}^{-3} \mathrm{KOH}$ solution:

(a) $\mathrm{HNO}_{3}\left(0.00411 \mathrm{~mol} \mathrm{dm}^{-3}\right)+\mathrm{KNO}_{3}\left(0.1 \mathrm{~mol} \mathrm{dm}^{-3}\right)$;

(b) Solution (a) $+\left(0.0012 \mathrm{~mol} \mathrm{dm}^{-3}\right)$ NAC;

(c) Solution (b) $+\left(0.0005 \mathrm{~mol} \mathrm{dm}^{-3}\right)$ metal ion;

(d) Solution (a) $+\left(0.0012 \mathrm{~mol} \mathrm{dm}^{-3}\right)$ amino acid;

(e) Solution (d) $+\left(0.0005 \mathrm{~mol} \mathrm{\textrm {dm } ^ { - 3 } )}\right.$ metal ion;

(f) Solution (a) $+\left(0.0012 \mathrm{~mol} \mathrm{dm}^{-3}\right) \mathrm{NAC}+\left(0.0012 \mathrm{~mol} \mathrm{dm}^{-3}\right)$ metal ion $+\left(0.0012 \mathrm{~mol} \mathrm{dm}^{-3}\right)$ amino acid.

All the titrations were performed at an ionic strength of $0.1 \mathrm{~mol} \mathrm{dm}^{-3} \mathrm{KNO}_{3}$ and at $25{ }^{\circ} \mathrm{C}$. The equations of Irving and Rossotti $i^{13,14}$ were used to determine the equilibrium constants of the said ligands and their metal complexes. The reported values were calculated using SCOGS computer program. 


\section{Spectrophotometeric studies}

The optical absorption spectra for different NAC- metal(II) complexes was recorded on a Shimadzu UV-160 spectrophotometer, in the borax ${ }^{15}$ buffer solution of $\mathrm{pH} 10$. The spectra's of these solutions in one cm quartz cells was recorded in the wave length region of 220-400 $\mathrm{nm}$. Mole ratio method was used to determine the stoichiometry of the binary NAC-metal(II) complexes, over a (1.5-3) $\times 10^{-4} \mathrm{~mol} \mathrm{dm}^{-3}$ concentration range. The extinction coefficients for complexes were also calculated at the respective absorbance maxima.

\section{Results and Discussion}

The acid dissociation constants of NAC, histidine, tyrosine and phenylalanine are summarized in Table 2. The values obtained are in good agreement with the literature data $^{16,17}$. The dissociation constants determined in this work were used throughout the calculation of chelate stability constants as these were determined at an ionic strength of $\mathrm{I}=0.1 \mathrm{~mol} \mathrm{dm}^{-3} \mathrm{KNO}_{3}$ and $25{ }^{\circ} \mathrm{C}$, the same as the conditions used for the ligand metal system.

Table 1. Principal electronic transitions in NAC-metal(II) complexes in terms of maximum absorption wavelength $\lambda_{\max (\mathrm{nm})}$ and molar extinction co-efficient $\varepsilon\left(\mathrm{dm}^{3} \mathrm{~mol}^{-1} \mathrm{~cm}^{-1}\right)$

\begin{tabular}{ccc}
\hline Metal ion & $\lambda_{\max , \mathrm{nm}}$ & $\varepsilon, \mathrm{dm}^{3} \mathrm{~mol}^{-1} \mathrm{~cm}^{-1}$ \\
\hline $\mathrm{Hg}(\mathrm{II})$ & 230 & 3821 \\
& 300 (shoulder) & 350 \\
$\mathrm{Cu}(\mathrm{II})$ & 339 & 3000 \\
$\mathrm{Zn}(\mathrm{II})$ & 235 & 844 \\
$\mathrm{Cd}(\mathrm{II})$ & 241 & 1200 \\
\hline
\end{tabular}

Table 2. Acid dissociation constants of ligands at $25^{\circ} \mathrm{C}$ and $\mathrm{I}=0.1 \mathrm{~mol} \mathrm{dm}^{-3} \mathrm{KNO}_{3}$.

\begin{tabular}{ccc}
\hline Ligand & $\log K_{1}{ }^{\mathrm{H}}$ & $\log K_{2}{ }^{\mathrm{H}}$ \\
\hline$N$-Acetylcysteine & $3.26 \pm 0.02$ & $9.64 \pm 0.03$ \\
Histidine & $6.03 \pm 0.04$ & $9.1 \pm 0.02$ \\
Tyrosine & $9.05 \pm 0.02$ & $10.11 \pm 0.02$ \\
Phenylalanine & ------ & $9.14 \pm 0.03$ \\
\hline
\end{tabular}

The metal ligand stability constants of the 1:1 and 1:2 NAC-Metal(II), ion systems are given in Table 3. Due to the formation of insoluble precipitate no calculations could be conducted on $\mathrm{Pb}(\mathrm{II})$ with NAC. A comparison of the metal stability constants show a decrease in the order $\mathrm{Hg}(\mathrm{II})>\mathrm{Cu}(\mathrm{II})>\mathrm{Cd}(\mathrm{II})>\mathrm{Zn}(\mathrm{II})$. As expected from the thermodynamic consideration $\log K_{\mathrm{MA} 2}$ is lower than $\log K_{\mathrm{MA}}$. The $\Delta \log K\left(\Delta \log K=\log K_{\mathrm{MA} 2}\right.$ $\left.-\log K_{\mathrm{MA}}\right)$ are negative Table 3 . As can be observed the difference is highest in case of $\mathrm{Hg}(\mathrm{II})$, due to the very low value of $\log K_{\mathrm{MA} 2}$. Similar results were also obtained by Lenz and Martel $^{18}$, while studying the interaction of $\mathrm{Hg}(\mathrm{II})$ with cysteine and $d$ - penicillamine (also sulfur donor ligands), where they concluded that $\mathrm{Hg}$ (II) forms extremely stable complexes of 1:1 type only and no 2:1 complex formation takes place. Our observation also leads to the same conclusion with regard to $\mathrm{Hg}$ (II)-NAC system. We tried to further investigate these observations by conducting UV-spectral spectroscopic studies on NAC-metal(II) complexes. UV absorbance spectra of $\mathrm{Hg}(\mathrm{II})-\mathrm{NAC}$ complexes are shown in Figure 1 and other observations are summarized in Table 1. For the $\mathrm{Hg}(\mathrm{II})-\mathrm{NAC}$ system the maxima at $230 \mathrm{~nm}$, like the shoulder at $260 \mathrm{~nm}$ increase as a function of added mercuric ion until an end point is observed at $\mathrm{Hg}(\mathrm{II})$ : NAC ratio of 1:1 (inset Figure 1), thus substantiating our findings. While as in case of other metal ions the stoichiometry was found to be $1: 2$. 
Table 3. Stability constants of $N$-acetylcysteine (A), Metal(II) $1: 1$ and 1:2 binary complexes at $25^{\circ} \mathrm{C}$ and $\mathrm{I}=0.1 \mathrm{~mol} \mathrm{dm}^{-3} \mathrm{KNO}_{3}$.

\begin{tabular}{llll}
\hline Metal Ion & $\log K_{\mathrm{MA}}$ & $\log K_{\mathrm{MA} 2}$ & $\Delta \log K$ \\
\hline $\mathrm{Hg}(\mathrm{II})$ & $11.23 \pm 0.04$ & $6.03 \pm 0.04$ & -5.2 \\
$\mathrm{Cu}(\mathrm{II})$ & $9.02 \pm 0.02$ & $7.33 \pm 0.03$ & -1.69 \\
$\mathrm{Zn}(\mathrm{II})$ & $7.04 \pm 0.02$ & $5.28 \pm 0.02$ & -1.76 \\
$\mathrm{Cd}(\mathrm{II})$ & $7.25 \pm 0.03$ & $6.31 \pm 0.02$ & -0.94 \\
\hline
\end{tabular}
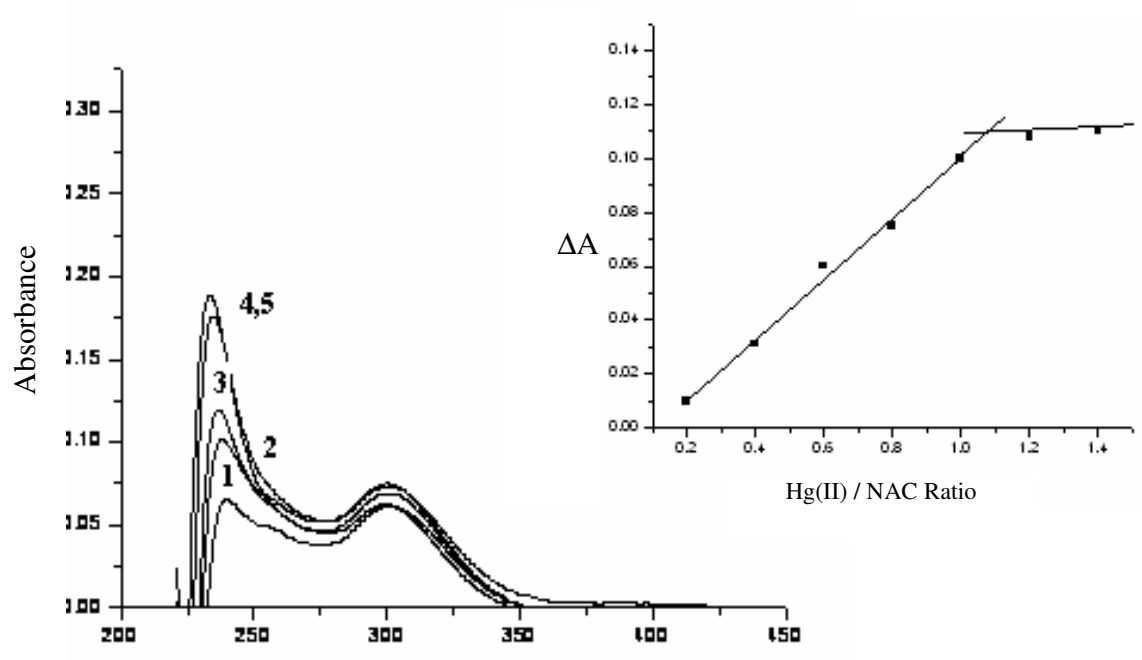

Wavelength, $\mathrm{nm}$

Figure 1. UV-spectra of Hg-NAC complexes obtained in the concentration range of (1.5-3) $\times 10^{-4} \mathrm{~mol} \mathrm{dm}^{-3}$. Spectra $1-5$ represent addition of $0.4,0.6,0.8,1.0$ and 1.2 equiv of $\mathrm{Hg} / \mathrm{NAC}$, respectively. Inset: Plot of absorbance change $\left(\Delta \mathrm{A}=\mathrm{A}_{\mathrm{Hg}-\mathrm{NAC}}-\mathrm{A}_{\mathrm{NAC}}\right)$ vs. ratio of $\mathrm{Hg}$ (II) to NAC, demonstrating 1:1 stoichiometry of the resulting NAC- $\mathrm{Hg}$ (II) complex at (230 nm).

Bands arising in the case of $\mathrm{Hg}$ (II) as well as other metal ions in the $230 \mathrm{~nm}$ region are assigned as $\mathrm{S} \rightarrow \mathrm{M}$ (II) (i.e. ligand to metal charge transfer bands ${ }^{19}$. The magnitude of the extinction coefficient (of the order of $10^{3} \mathrm{dm}^{3} \mathrm{~mol}^{-1} \mathrm{~cm}^{-1}$ ) support assignment of these bands as charge - transfer transitions. Also the fact that $\lambda_{\max }$ obtained for different metal ions does not differ much, thus supporting the attribution of these bands as ligand to metal charge transfer transitions indicating that sulfur ${ }^{11}$ is the donor atom in case of NAC.

The stability constants of the 1:1:1 ternary complexes of the metal ions with NAC as a primary ligand and histidine, tyrosine and phenylalanine as secondary ligands are summarized in Table 4-6. The stability of the ternary complexes $(1: 1: 1)$ as compared to the binary complexes can be quantified by calculation of $\Delta \log K^{\prime}$ which is given by the following expressions;

or more appropriately as,

$$
\Delta \log \mathrm{K}^{\prime}=\log K_{M A L}^{M A}-\log K_{M L}^{M}
$$

$$
\Delta \log \mathrm{K}^{\prime}=\log \beta_{M A L}^{M A}-\log K_{M L}^{M}-\log K_{M A}^{M}
$$

(A= NAC, and L $=$ Amino acid) where $\log K_{M A}^{M}, \log K_{M L}^{M}$ and $\log \beta_{M A L}^{M A}$.can be expressed by the following equilibrium reactions (charges have been omitted for simplicity) 


$$
\begin{aligned}
\mathrm{M}+\mathrm{A} & \leftrightarrow \mathrm{MA} \\
\mathrm{K}_{\mathrm{MA}}^{M} & =\frac{[\mathrm{MA}]}{[\mathrm{M}][\mathrm{A}]} \\
\mathrm{M}+\mathrm{A}+\mathrm{L} & \leftrightarrow \mathrm{MAL} \\
\mathrm{K}_{\mathrm{MAL}}^{M A} & =\frac{[\mathrm{MAL}]}{[\mathrm{MA}][\mathrm{L}]}
\end{aligned}
$$

The overall stability constant for the mixed ligand complex MAL is given by equation (6).

$$
\begin{aligned}
\mathrm{MA}+\mathrm{L} & \leftrightarrow \mathrm{MAL} \\
\beta_{\mathrm{MAL}}^{M} & =\frac{[\mathrm{MAL}]}{[\mathrm{M}][\mathrm{A}][\mathrm{L}]}
\end{aligned}
$$

In the above equations $\mathrm{M}$ represents the solvated electron pair accepting metal ion, $\mathrm{A}$ represents the primary ligand and $\mathrm{L}$ is the secondary ligand, which leads to the formation of a ternary or mixed ligand complex MAL.

Table 4. Stability constants of 1:1:1 ternary complexes involving Metal(II)-NAC-Histidine system at $25^{\circ} \mathrm{C}$ and $\mathrm{I}=0.1 \mathrm{~mol} \mathrm{dm}{ }^{-3} \mathrm{KNO}_{3}$.

\begin{tabular}{ccccc}
\hline Metal Ion & $\log K_{M L}^{M}$ & $\log K_{M A L}^{M A}$ & $\Delta \log \mathrm{K}$ & $-\Delta G^{\mathrm{a}} / \mathrm{kJmol}^{-1}$ \\
\hline $\mathrm{Pb}(\mathrm{II})$ & $5.97 \pm 0.01$ & --- & --- & --- \\
$\mathrm{Cu}(\mathrm{II})$ & $10.11 \pm 0.01$ & $5.96 \pm 0.02$ & -0.42 & 44.18 \\
$\mathrm{Zn}(\mathrm{II})$ & $6.38 \pm 0.02$ & $5.96 \pm 0.02$ & -0.42 & 44.18 \\
$\mathrm{Cd}(\mathrm{II})$ & $5.67 \pm 0.02$ & $5.25 \pm 0.02$ & -0.42 & 41.05 \\
\hline
\end{tabular}

Table 5. Stability constants of 1:1:1 ternary complexes involving Metal(II)-NAC-Tyrosine system at $25^{\circ} \mathrm{C}$ and $\mathrm{I}=0.1 \mathrm{~mol} \mathrm{dm}{ }^{-3} \mathrm{KNO}_{3}$.

\begin{tabular}{ccccc}
\hline Metal Ion & $\log _{K_{M L}^{M}}$ & $\log K_{M A L}^{M A}$ & $\Delta \log \mathrm{K}$ & $-\Delta G^{\mathrm{a}} / \mathrm{kJmol}^{-1}$ \\
\hline $\mathrm{Pb}(\mathrm{II})$ & $4.78 \pm 0.03$ & --- & --- & --- \\
$\mathrm{Cu}(\mathrm{II})$ & $7.77 \pm 0.03$ & $5.98 \pm 0.04$ & -1.79 & 44.27 \\
$\mathrm{Zn}(\mathrm{II})$ & $4.27 \pm 0.02$ & $3.78 \pm 0.03$ & -0.49 & 32.80 \\
$\mathrm{Cd}(\mathrm{II})$ & $3.61 \pm 0.04$ & $3.48 \pm 0.03$ & -0.13 & 30.87 \\
\hline
\end{tabular}

Table 6. Stability constants of $1: 1: 1$ ternary complexes involving Metal (II)-NACPhenylalanine system at $25^{\circ} \mathrm{C}$ and $\mathrm{I}=0.1 \mathrm{~mol} \mathrm{dm}^{-3} \mathrm{KNO}_{3}$.

\begin{tabular}{ccccc}
\hline Metal Ion & $\log _{K_{M L}^{M}}$ & $\log K_{M A L}^{M A}$ & $\Delta \log \mathrm{K}$ & $-\Delta G^{\mathrm{a}} / \mathrm{kJmol}^{-1}$ \\
\hline $\mathrm{Pb}(\mathrm{II})$ & $4.26 \pm 0.02$ & --- & --- & --- \\
$\mathrm{Cu}(\mathrm{II})$ & $7.83 \pm 0.05$ & $6.26 \pm 0.03$ & -1.57 & 45.40 \\
$\mathrm{Zn}(\mathrm{II})$ & $4.59 \pm 0.04$ & $4.49 \pm 0.03$ & -0.1 & 37.18 \\
$\mathrm{Cd}(\mathrm{II})$ & $4.04 \pm 0.04$ & $3.65 \pm 0.02$ & -0.39 & 32.05 \\
\hline
\end{tabular}

${ }^{a} \Delta G$, free energy of formation of the ternary complex : $\Delta G=-2.303 R T \log K_{M A L}$.

It can be observed from Table 4-6 that $\log K_{\mathrm{MAL}}$ values for all the Metal -NAC - Amino acid 1:1:1 system are lower than that of the $\log K_{\mathrm{ML}} 1: 1$ complexes resulting in negative value of $\Delta \log K^{\prime}$. Besides the steric factors the lower stability of the ternary systems may be 
due to the repulsion between the negative charges around the metal ion, due to the presence of secondary ligands. $\Delta \log K^{\prime}$ value is less negative for phenylalanine and tyrosine. The stability in case of tyrosine can be due to hydrogen bonding between free $\mathrm{COO}^{-}$group of $\mathrm{NAC}$ and free $\mathrm{OH}$ group of tyrosine, while as in case of phenylalanine the interaction of non-coordinated aromatic group with the metal ion can be considered ${ }^{20}$.

\section{References}

1. Williams R J P, The Enzymes: Academic Press Inc, New York, 1959, 1.

2. Antolini L, Menabue L, Prampolini P and Saladini M, Inorganica Chim Acta, 1982, 66, 19.

3. Perkin's D J, Biochem J., 1953, 55, 649.

4. Stricks W and Kolthoff I M, J Am Chem Soc., 1953, 75, 5673.

5. Cheesman B V, Arnold A P and Rabenstein D L, J Am Chem Soc., 1988, 110, 6359.

6. Klotz I M, Czerlinski G H and Fiess H A, J Am Chem Soc., 1958, 80, 2920.

7. Tewari B B, Russian J Coord Chem., 2003, 29, 441.

8. Casas J S and Jones M M, J Inorg NuclChem., 1980, 42, 99.

9. Guzeloglu S, Yalcin G and Pekin M, J Organomet Chem., 1998, 568, 143.

10. Kadima W, Rabenstein and.Dallas L, J Inorg Biochem., 1990, 38, 277.

11. Martin R P, Pettit-Ramel M M and Schariff J P, Metal Ion in Biological Systems, New York, 1973, 2.

12. Cohn E J and Edsall J T, Proteins, Amino Acids and Peptides, Newyork ,1943.

13 Irving H M and Rossotti H S, J Chem Soc., 1953, 3397.

14. Irving H M and Rossotti H S, J Chem Soc., 1954, 2904.

15. Bates R G and Bower V E, Anal Chem., 1956, 1322.

16. Lehninger A L, Biochemistry, $2^{\text {nd }}$. Ed., Worth Publishers, New York, 1975.

17. Martell A E and Smith R M, Critical Stability Constants, Vol 2, Amines, Plenum Press, New York, London, 1975.

18. Lenz G R and Martell A E, Biochem., 1964, 3, 745.

19. Vasak M, Kagi J H R and Hill H A O, Biochem., 1981, 20, 2852.

20. Ullah M R and Battacharya P K, Indian J Chem., 1990, 29A, 150. 


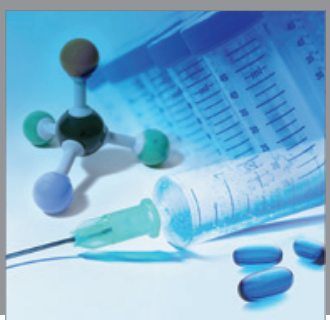

International Journal of

Medicinal Chemistry

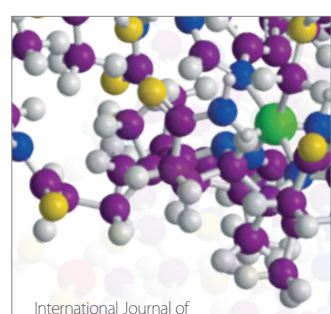

Carbohydrate Chemistry

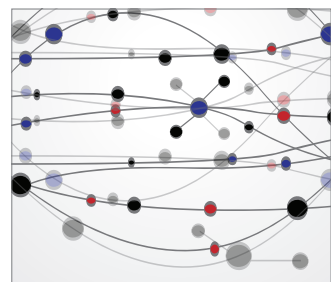

The Scientific World Journal
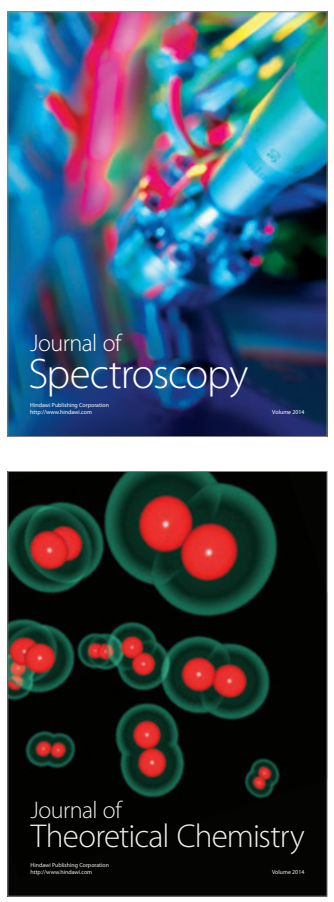
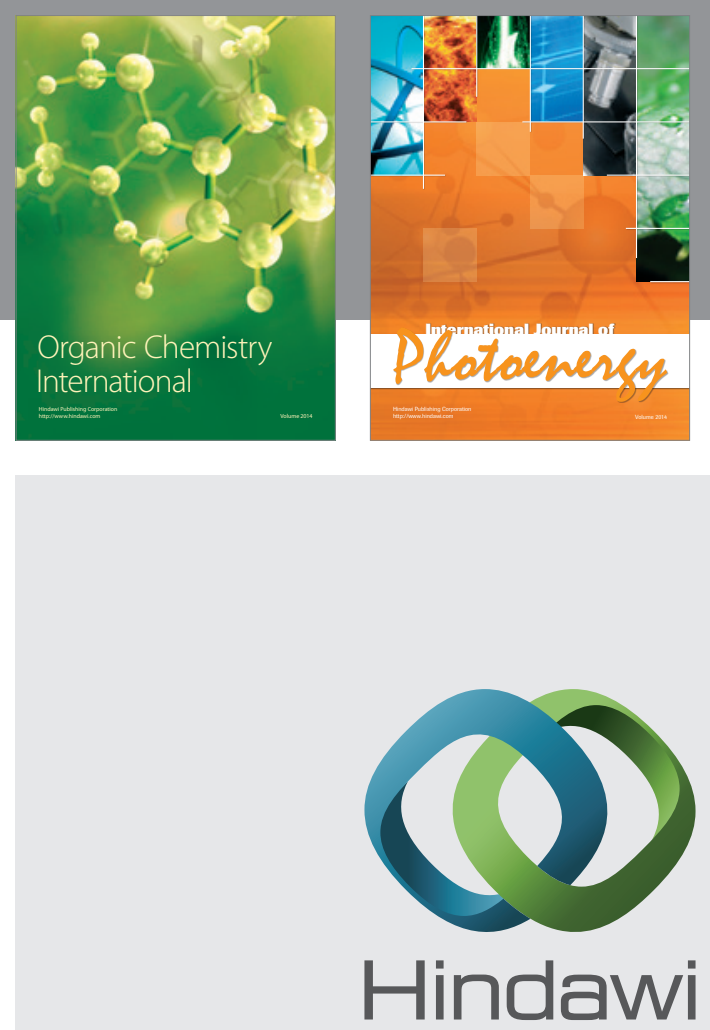

Submit your manuscripts at

http://www.hindawi.com
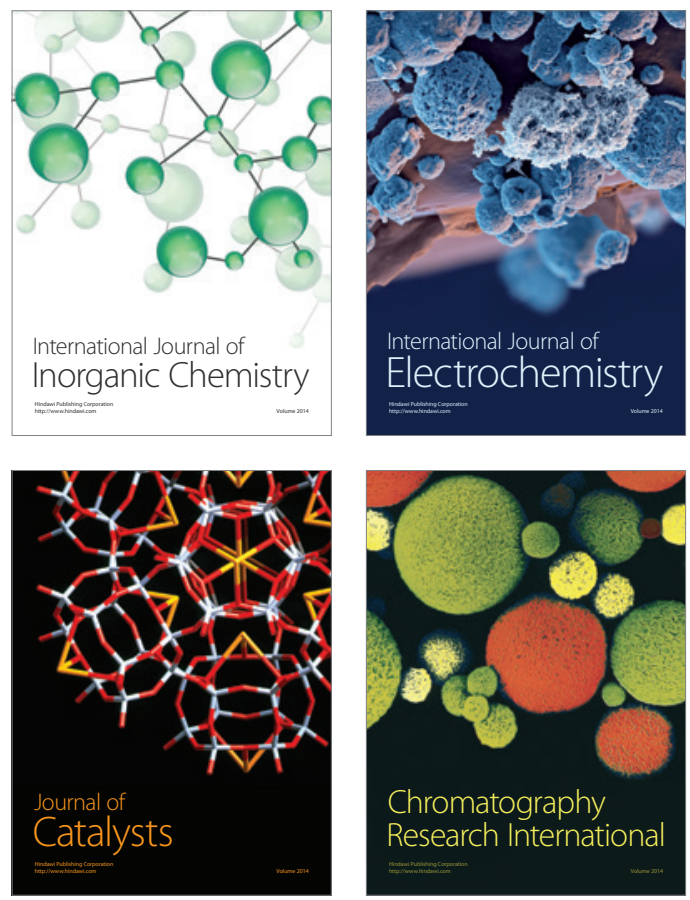
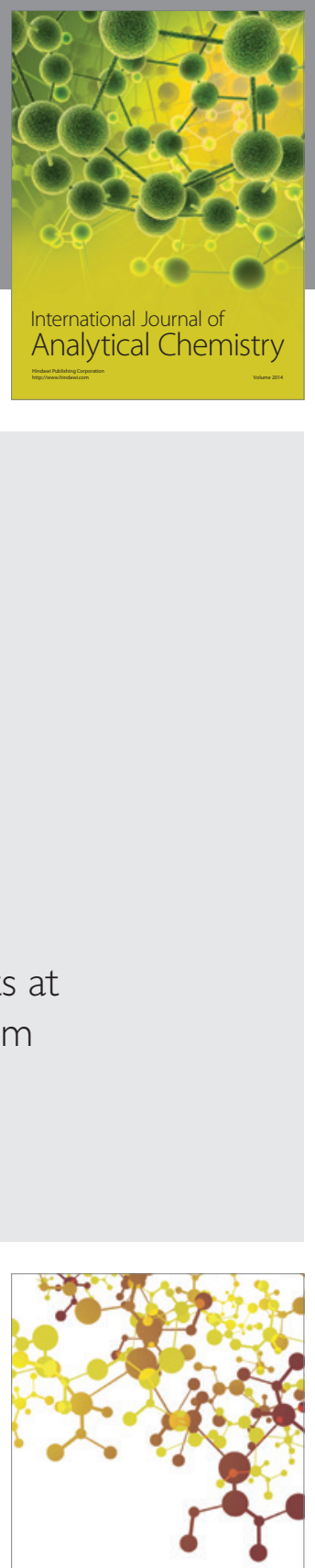

Journal of

Applied Chemistry
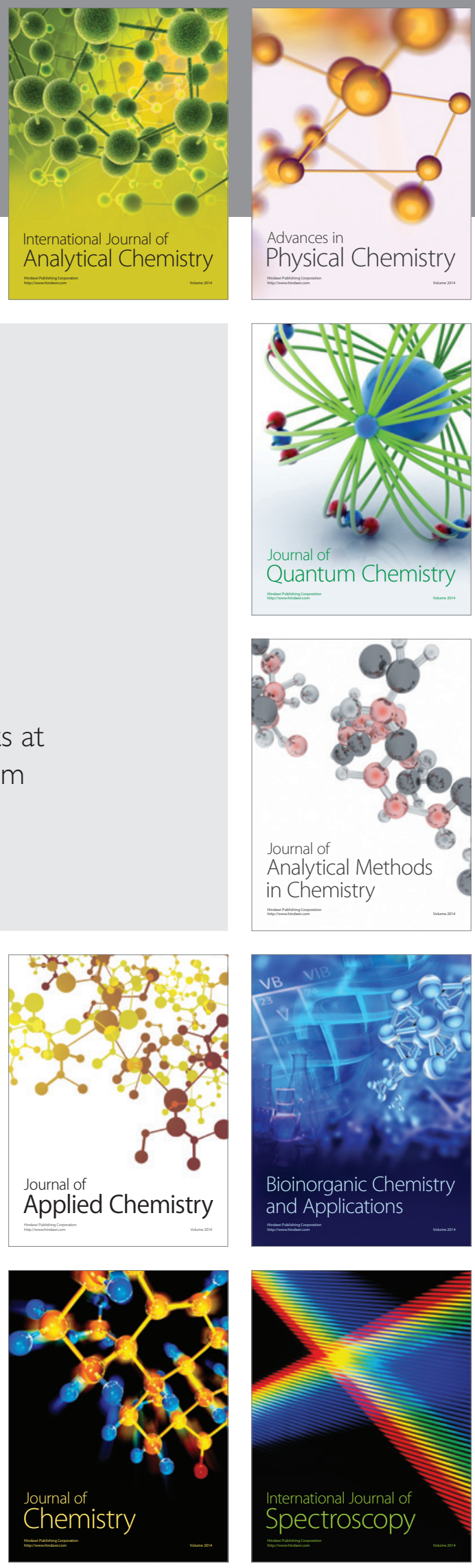